\title{
EXPOSURE BERITA TERHADAP MINAT PARIWISATA LOMBOK PASCA GEMPA
}

\author{
Gusmia Arianti \\ Program Studi Ilmu Komunikasi, Universitas Al Azhar Indonesia, Jakarta. \\ gusmia.arianti@uai.ac.id
}

Diajukan: 17-03-2019; Direview: 02-05-2019; Diterima: 23-06-2019;

\begin{abstract}
The focus of the research is looking at the influence of exposure to news that appears on television against the interest in visiting. The study was conducted with a survey method for 66 respondents, data collection was conducted in December 2018-February 2019, by using linear regression analysis. The exposure of the media to become an independent variable and interest in visits are dependent variables. The results showed that news exposure to television mass media about Lombok tourism after the earthquake in August 2018 then gave a significant positive effect on the interest of community visits to Lombok. Television is considered to play an important role in the dissemination of information. This is in accordance with the uses and effect theory, where the need for information will affect the behavior of recipients of information.
\end{abstract}

Keywords: Exposure News, Post Earthquake, Tourism

\begin{abstract}
Abstrak
Penelitian ini bertujuan untuk melihat pengaruh terpaan berita yang dimunculkan di televisi terhadap minat berkunjung wisatawan ke Lombok pasca terjadinya bencana. Penelitian dilakukan dengan metode survei kepada 66 responden, pengumpulan data dilakukan September-November 2018, dengan menggunakan analisis regresi linier. Terpaan media menjadi variabel bebas (independent variable) dan minat kunjungan menjadi variabel terikat (dependent variable). Hasil penelitian menunjukan bahwa terpaan berita pada media massa televisi mengenai pariwisata Lombok pasca terjadinya gempa di bulan Agustus 2018 lalu memberikan pengaruh signifikan positif terhadap minat kunjungan masyarakat ke Lombok. Televisi dirasa memainkan peranan penting dalam penyebaran informasi. Hal ini sesuai dengan teori uses and effect, dimana kebutuhan akan informasi akan mempengaruhi perilaku penerima informasi.
\end{abstract}

Kata Kunci: Pariwisata, Pasca Gempa, Terpaan Berita

\section{PENDAHULUAN}

$\mathrm{O}$ bjek-objek wisata yang terdapat di Indonesia merupakan salah satu dari kekayaan alam yang patut untuk dibanggakan. Setiap daerah di Indonesia memiliki keunikan baik dari segi keindahan alamnya maupun adat istiadat yang ada di daerah tersebut sehingga menarik minat wisatawan untuk mengunjunginya. Daya tarik pariwisata yang dimiliki oleh Indonesia menjadikan Negara ini sebagai salah satu pilihan destinasi baik bagi wisatawan lokal maupun mancanegara.

Kekayaan alam dan kebudayaan Indonesia merupakan komponen penting dalam pariwisata
Indonesia. Indonesia merupakan Negara kepulauan terbesar di dunia dengan 17.058 pulau dan hanya 30-35 persen yang berpenghuni (Liputan6.com: 2014 diakses pada 20 Februari 2019). Tempattempat wisata itu didukung dengan warisan budaya yang kaya yang mencerminkan sejarah dan keberagaman etnis Indonesia yang dinamis dengan 719 bahasa daerah yang dituturkan di seluruh kepulauan.

Indonesia juga menjadi salah satu negara yang mempunyai banyak sekali wisata halal. Berdasarkan informasi yang dikutip dari pressrelease.kontan.co.id (2018) yang diakses pada 21 Desember 2018, April 2018 saat Mastercard- 
Cresent Rating meluncurkan hasil studi Global Travel Indeks (GMTI), Indonesia mendapatkan peringkat ke-dua destinasi wisata halal di dunia. Salah satu destinasi yang akan terus dipromosikan adalah pulau Lombok. Berdasarkan siaran pers www.kemenpar.co.id (2018) (diakses pada 20 Februari 2018), Lombok kembali terpilih sebagai destinasi wisata halal (halal tourism) terbaik di Indonesia dengan nilai skor tertinggi mencapai 70 mengungguli 10 destinasi lain di Tanah Air. Lombok adalah salah satu pulau di Nusa Tenggara Barat yang menawarkan banyak sekali destinasi wisata baik darat maupun laut.

Lombok (di Nusa Tenggara Barat) atau yang dikenal dengan Bumi Seribu Masjid merupakan salah satu destinasi wisata yang menarik terutama dari segi eco-tourism. Eco-tourism sendiri sangat sesuai dengan visi dan misi kepariwisataan berkelanjutan di Lombok yaitu, "Lombok menjadi destinasi wisata yang berbasis alam dan budaya, yang berdaya saing dan berkelanjutan." Ecotourism adalah suatu bentuk perjalanan wisata ke daerah alami dengan tujuan mengkonservasi lingkungan dan melestarikan kehidupan dan kesejahteraan penduduk setempat.

Namun pada tanggal 18 Agustus 2018, terjadi gempa yang sangat besar di Lombok. Badan Klimatologi dan Geofisika (BMKG) yang diakses melalui laman bmkg.go.id (2018) mencatat bahwa gempa paling besar terjadi pada 6,9 SR dan gempa tersebut sudah merusak semua bangunan dan fasilitas di Lombok. Tercatat setelah satu bulan gempa itu terjadi, Lombok sudah terkena gempa sebanyak 1.973 kali. Bencana gempa yang terjadi ketika sumberdaya atau kapasitas yang tersedia sangat tidak memadai dalam mengatasi ancaman yang menyebabkan kerugian dan kehilangan nyawa, materi, dan lingkungan. Situasi ini adalah hasil dari kemerosotan di bidang ekologi, ekonomi, sosial, dan politik karena terjadinya bencana.

Berdasarkan data yang dikutip dari www. cnnindonesia.com (2018) diakses pada 17 Maret 2018) tercatat sebanyak 515 orang meninggal dunia, 7.145 orang mengalami luka-luka dan 431.416 orang mengungsi, jumlah rumah rusak sebanyak 73.843 unit dan 798 fasilitas umum dan social lainnya ikut rusak. Total kerugian dari bencana ini mencapai Rp 7,7 Triliun.

Informasi yang diakses pada 20 Januari 2019 terkait dengan pemulihan pasca gempa yang dilakukan Lombok pada (www.tempo.co.id 2019), Untuk pemulihan kegiatan pariwisata di NTB, Tim Crisis Center Kementerian Pariwisata (Kemenpar) telah berhasil menyelenggarakan 280 paket wisata. Tahun 2019 ini, angka kunjungan wisatawan ditargetkan bisa mendatangkan empat juta wisatawan. Pada tahun 2017, angka kunjungan wisatawan ke NTB sebanyak 3,5 juta wisatawan atau 3.508.903 wisatawan. 2.078.654 di antaranya Wisatawan Nusantara (Wisnus) dan 1.430.249 wisatawan Mancanegara (Wisman). Tingginya angka kunjungan sebelum bencana melanda haruslah menjadi penggerak atau kunci dalam membangun kembali pariwisata Lombok. Dinas Pariwisata NTB menyiapkan empat diantara 100 kegiatan pariwisata nasional yaitu Festival Bau Nyale di Lombok Tengah, Festival Khazanah Ramadhan di Mataram, Festival Pesona Tambora di Kabupaten Dompu dan Bima serta Festival Pesona Moyo di Kabupaten Sumbawa.

Menurut Menteri Pariwisata Republik Indonesia Arif Yahya, pemulihan yang harus dilakukan pasca gempa adalah dengan memulihkan sumber daya manusia dan masyarakat, pemulihan destinasi pariwisata dan pemulihan pemasaran dengan melakukan image promotion dan product promotion seperti mengikuti event di dalam maupun di luar negeri. Sales Mission Famtrip mengundang Tour operator dan Travel Agency, Corporate dan media, menambah jumlah even MICE di Lombok (Branding, Advertising and Salling) (opiniartikel.kampung-media.com, 2018 di akses pada 20 Februari 2019).

Dalam mendukung pemasaran pariwisata, komunikasi berperan baik pada komponen maupun elemen-elemen seperti media dan konten komunikasi, seperti mengkomunikasikan destinasi, dan sumber daya kepada wisatawan dan seluruh stakeholder pariwisata termasuk membentuk kelembagaan pariwisata (Bungin, 2015: 86-88). Keberadaan media dalam kehidupan masyarakat telah menjadi bagian penting yang digunakan untuk pemenuhan informasi mereka. Sesuai dengan karakteristik masyarakatnya, media di Indonesia muncul dalam berbagai bentuk dan wujudnya, baik yang masuk dalam kategori media tradisional, media massa (tradisional ataupun elektronik) dan juga beragam media baru yang konvergen satu 
dengan lainnya. Kehidupan masyarakat Indonesia menempatkan media menjadi bagian penting dalam seluruh aspek kehidupan masyarakat. Media diharapkan memainkan peran yang penting dalam setiap peristiwa bencana. Media massa menjadi penghubung bagi semua pihak-pihak yang berkepentingan, baik dalam situasi prabencana, pada saat bencana terjadi maupun pasca-bencana.

Pada penelitian ini melihat bagaimana media massa khususnya (baik cetak, elektronik, serta internet sebagai media baru) mengupas hal yang berkaitan dengan bencana, khususnya bencana yang terjadi di Lombok. Media dalam hal ini mampu mengemas fenomena sehingga media muncul menjadi agen penting sebagai perantara antara masyarakat dan para pengambil kebijakan. Pemberitaan yang muncul baik di media massa maupun media sosial terkait dengan pariwisata di Lombok pasca terjadi gempa menarik untuk diteliti. Penelitian dilakukan untuk menganalisis terpaan media memberikan pengaruh terhadap minat wisatawan untuk berkunjung ke Lombok pasca terjadinya bencana.

Secara akademis, penelitian ini diharapkan dapat menstimulasi penelitian-penelitian baru di ranah ilmu komunikasi yang secara teoretis dapat digunakan untuk memotivasi segala kegiatan komunikasi pemasaran pariwisata. Secara praktis, penelitian ini diharapkan mampu memberikan identifikasi, representasi, analisis, visualisasi dari hal-hal terkait untuk kegiatan komunikasi pariwisatavbagi para stakeholder dan organisasi. Hasil penelitian dapat mendukung institusi atau lembaga pengelola pariwisata serta pembuat kebijakan, khususnya dalam menyusun strategi kebijakan komunikasi pariwisata, dan secara umum dapat menjadi faktor penunjang yang strategis dalam melakukan promosi pemasaran pariwisata Indonesia.

Berdasarkan latar belakang di atas, maka tujuan penelitian ini adalah untuk menganalisis terpaan media massa terutama berita di televisi terhadap minat berkunjung ke Lombok pasca terjadinya gempa pada Agustus 2018.

\section{LITERATUR DAN METODOLOGI}

\section{Komunikasi Pariwisata}

Setiap Negara memiliki citra yang unik dalam persepsi orang. Menurut Febrina (2018:79) Citra destinasi berdasarkan kepada ciri-ciri langsung dari pengamatan atau pengukuran seperti pemandangan, atrraction, penginapan, dan harga. Sementara yang lain dapat didasarkan pada ciri-ciri abstrak tidak berwujud seperti keramahan, keamanan, dan suasana. Public Relation dalam hal ini melibatkan manajemen untuk menghadapi persoalan atau permasalahan, membantu manajemen dalam mengikuti dan memanfaatkan perubahan secara efektif. PR dapat membantu sektor pariwisata untuk mewujudkan fungsi manajemen yang baik antara organisasi dan publiknya supaya wisatawan tertarik dengan pariwisata yang kita tawarkan.

Menurut Zaluku dan Meyers (2009:3) menyatakan bahwa pariwisata adalah aktivitas perjalanan yang dilakukan untuk sementara waktu dari tempat tinggal semula kedaerah tujuan dengan alas an bukan untuk menetap atau mencari nafkah melainkan hanya untuk bersenang-senang, memenuhi rasa ingin tahu, menghabiskan waktu senggang atau waktu libur serta tujuan-tujuan lainnya.

Bidang pariwisata sering kali menjadi pemasukan yang besar bagi negara dan sebenarnya pemerintah memiliki kepentingan terhadap destinasi pariwisata yang harus dikembangkan, yaitu sebagai ruang publik bagi warga negaranya. Destinasi wisata bukan saja sebagai ruang rekreasi, namun juga sebagai ruang melepaskan tekanantekanan psikologis warga negara dari berbagai kesibukan hidup dan kesulitan hidup (Rejeki dan Arianti 2018:155). Komunikasi memainkan peranan yang penting tidak hanya pada pemasaran pariwisata saja, tetap juga menginfomasikan aksesibilitas, destinasi dan sumber kepada wisatawan. Komunikasi pariwisata dalam hal ini menyangkutmedia atau saluran-salurankomunikasi yang digunakan dalam menyampaikan informasi. Informasi mengenai transportasi, dampak informasi terhadap masyarakat pariwisata, sampai pada umpan balik yang diharapkan. Selain itu juga menyangkut tentang alat dan jenis transportasi, anggaran yang diperlukan, masalah keamanan, dan keselamatan transportasi, transportasi alternative, dan koneksitas dengan akomodasi dan lain-lain.

Bungin (2015:46) menyatakan bahwa komunikasi memainkan peran dalam menyiapkan konten pesan yang harus disampaikan kepada 
masyarakat atau wisatawan, tentang apa yang seharusnya mereka tahu terkait media-media pemasaran, destinasi, aksesibilitas dan SDM serta kelembagaan pariwisata. Komunikasi juga berperan menyiapkan konten pesan yang harus disampaikan kepada masyarakat atau wisatawan, tentang apa yang seharusnya mereka tahu tentang media-media pemasaran, tentang destinasi, aksesibilitas dan SDM serta kelembagaan pariwisata. Dalam perspektif modern, komponen pemasaran, destinasi, aksesibilitas, SDM, dan kelembagaan pariwisata, serta elemen-elemen yang ada menjadi kesatuan produk pariwisata di sebuah destinasi yang dikemas di dalam suatu brand destinasi, sehingga destinasi, aksesibilitas, pemasaran, SDM dan kelembagaan pariwisata menjadi kesatuan produk pariwisata.

Menurut Sumiyati dan Murdianto (2018:171), strategi komunikasi pemasaran merupakan salah satu faktor yang sangat mempengaruhi jumlah pengunjung di suatu obyek wisata karena merupakan suatu rancangan bagaimana mempengaruhi masyarakat dengan berbagai cara sehingga masyarakat mengetahui, kemudian tertarik hingga berkunjung dan bahkan berkunjung kembali bagi wisatawan yang sudah pernah berkunjung.

Pemasaran destinasi

pariwisata mengorientasikan pada permintaan, kepuasan, dan nilai-nilai wisatawan di dalam dan di luar negeri berdasarkan segmentasi dan target pasar tertentu. Pemasaran dari industri pariwisata salah satunya dapat dilakukan melalui kegiatan pengembangan promosi dan komunikasi yang terdiri dari kegiatan kehumasan, publikasi, penjualan secara personal, dan promosi penjualan (Budianto, Mulyasari dan Kholisoh: 2013).

\section{Exposure Berita}

Exposure atau yang dikenal dengan terpaan/ pemaparan merupakan tahap pertama dari proses pengolahan informasi. Terpaan media berkaitan dengan beberapa banyak orang yang melihat program yang ditayangkan di suatu media. Pengertian media exposure menurut pendapat Larry Shore (Kriyantono, 2006:209) adalah sebagai berikut:

"media exposure is more complicated than access, because it's deal not only white whether a person is actually range of the particular mass media, but also whether a person is actually expose to the message, expose is hearing, seeing, reading of more generally experiencing with least a minimal amount of interest the media message"

Berdasarkan pendapat diatas disimpulkan bahwa seseorang tidak dapat dikatakan mengekspose media apabila ia hanya terlibat dalam lingkungan fisik media. Media exposes akan terjadi jika khalayak secara sungguhsunggu membuka diri terhadap pesan-pesan yang diberikan mesia. Bentuk nyata dari terpaan media adalah mendengar, melihat, menonton, membaca atau ikut membaurkan diri dengan isi media.

Exposure adalah kegiatan yang dilakukan oleh para pemasar untuk menyampaikan stimulus kepada konsumen. Stimulus bisa berbentuk iklan, kemasan, merek, dan hadiah. Stimulus adalah input apapun yang datang dari pemasar yang disampaikan kepada konsumen melalui berbagai media, seperti toko, iklan luar ruang, televisi, radio, koran, majalah, dan lain-lain. Stimulus ini akan dirasakan oleh satu atau lebih pancaindera konsumen (Sumarwan, 2011:5). Menurut Kotler dan Keller (2007:204) perencanaan media harus mengetahui kemampuan jenis-jenis media utama untuk menghasilkan jangkauan, frekuensi dan dampak.

Dalam proses terpaan, terdapat beberapa faktor yang menjadi fokus utama, diantaranya: 1) Frekuensi merupakan pengulangan pesan; 2) Intensitas adalah selesai atau tidaknya khalayak menonton tayangan; 3) Durasi merupakan lamanya tayangan saat ditayangkan yang dapat dihitung dalam satuan tahun, bulan, minggu, hari, jam, dan detik (Rakhmat, 2011: 66).

Frekuensi merupakan banyaknya pengulangan perilaku yang menjadi target. Menonton tayangan televisi dapat berlangsung dalam frekuensi yang berbeda-beda, dapat seminggu sekali, dua minggu sekali, atau satu bulan sekali, tergantung dari indivisu yang bersangkutan. Intensitas (perhatian) adalah proses mental ketika stimuli atau rangkaian stimuli menonton dalam kesadaran pada saat stimuli melemah. Indikator intensitas dalam penelitian diukur dari faktor eksternal penarik perhatian dan factor internal pengaruh perhatian. Durasi atau lamanya penayangan program, suatu program terdiri atas program yang dapat bertahan 
lama. Meskipun bukan bagian kognisi dalam pengertian secara ketat, paparan (exposure) pada informasi tersebut penting bagi proses interpretasi konsumen-tidak ada paparan informasi, tidak ada interpretasi. Konsumen mendapat informasi dalam lingkungan, termasuk strategi pemasaran, terutama melalui perilaku mereka. Oleh karena itu, kita dapat membedakan dua jenis paparan pada informasi pemasaran. Bertujuan atau paparan sengaja (intentional exposure) dan acak paparan kebetulan (accidental exposure).

\section{Minat}

Menurut Slamet (2010:57) minat merupakan faktor psikologis yang dapat menentukan suatu pilihan seseorang dan merupakan faktor yang sangat penting untuk suatu kemajuan dan keberhasilan seseorang. Seseorang mengerjakan suatu pekerjaan dengan disertai minat, pada umumnya akan lebih baik. Minat seseorang terhadap suatu objek akan lebih kelihatan apabila objek tersebut sesuai dengan sasaran dan berkaitan dengan keinginan dan kebutuhan orang yang bersangkutan. Jadi minat adalah suatu kecenderungan hati yang dimiliki oleh seseorang, baik itu rasa suka maupun rasa ingin memiliki sesuatu tanpa memperdulikan hal yang lain.

Dimensi dari minat berkunjung menurut Middleton et al. (2009) yang dikutip Oktaria (2018:7), terdiri atas problem recognition, information gathering, evaluasi, decision making, dan evaluation of post-purchase. Akan tetapi, dimensi yang digunakan dalam penelitian ini hanya dibatasi hingga evaluasi mengingat minat berkunjung belum sampai pada tahap decision making dan evaluation of post-purchase.

Pada indikator problem recognition akan menanyakan pendapat responden tentang keinginan untuk melakukan kunjungan karena adanya dorongan kebutuhan maupun upaya untuk meningkatkan kepuasan. Information gathering responden yang bersangkutan akan ditanya dimana mencari informasi terkait yang diminatinya. Pada evaluation responden akan mengukur serta membandingkan informasi yang didapat dari pencarian sebelumnya sehingga individu dapat memutuskan untuk menolak atau melakukan kunjungan.

Pendekatan teori yang digunakan dalam penelitian ini adalah efek media massa terhadap perilaku penontonnya. Menurut Arianti, Saleh dan Priatna (2015:43), komunikasi selain bertujuan menginformasikan, juga dapat mempengaruhi perilaku penerima informasi. Teori Uses and effects menyatakan bahwa kebutuhan hanya salah satu dari faktor-faktor yang menyebabkan terjadinya penggunaan media. Karakteristik individu, harapan dan persepsi terhadap media, dan tingkat akses kepada media, akan membawa individu kepada keputusan untuk menggunakan atau tidak menggunakan isi media massa. Penggunaan pada jenis dan isi media sesuai dengan motif untuk memenuhi kebutuhan, yang berbeda antara satu komunikan dengan komunikan lainnya. Orang yang berbeda dapat memilih jenis da nisi media yang sama maupun berbeda, pilihan pada media dapat juga pada lebih dari satu media untuk isi yang sama. Terdapat tiga aspek efek pesan dari media massa, diantaranya: efek kognitif, efek afektif dan efek behavioral.

Desain penelitian adalah perencanaan mendetail yang digunakan sebagai panduan untuk mencapai tujuan penelitian. Penelitian didesain sebagai penelitian survei deskriptif eksplanatori yang bersifat korelasional dan pengaruh. Data primer diperoleh dengan melakukan wawancara langsung dengan responden. Metode survei merupakan metode yang mengambil sampel dari satu kelompok populasi dan menggunakan kuesioner yang terstruktur sebagai alat pengumpulan data yang pokok untuk mendapatkan informasi yang spesifik. Fokus penelitian adalah menganalisis pengaruh terpaan berita pada media televisi terhadap minat berkunjung wisatwan pasca terjadinya bencana. Oleh karena itu, pada penelitian peubah yang digunakan terdiri dari terpaan media sebagai peubah bebas (independent variable), dan minat berkunjung sebagai peubah terikat (dependent variable).

Penelitian ini menggunakan pendekatan kuantitatif melalui survey terhadap 66 mahasiswa tingkat dua Universitas Al Azhar Indonesia dengan kriteria belum pernah ke Lombok. Pengumpulan data dilakukan pada bulan September-November 2018. Sampel dipilih secara bertujuan (purposive sampling). Purposive sampling merupakan sampel non-acak yang menggunakan berbagai metode untuk mencari semua kemungkinan yang 
populasinya sangat luas (Neuman, 2011:278). Analisis data menggunakan analisis regresi linier.

\section{TEMUAN DAN DISKUSI}

Pariwisata saat ini merupakan sebuah industri besar yang juga digunakan untuk mengenalkan negara ke dunia internasional. Perkembangan teknologi membuat dunia seakan-akan tanpa jarak, sehingga mobilitas masyarakat semakin mudah. Dampaknya adalah makin berkembangnya bisnis pariwisata sebagai primadona pemasukan devisa suatu negara. Selain itu, pariwisata juga menjadi bahan untuk menciptakan positioning sebuah Negara dimata global. Misalnya, Malaysia menyatakan dirinya sebagai "The heart of Asia" sebagai tagline dari promosi pariwisatanya yang seakan ingin menempatkan negara tersebut sebagai pusat dari Asia. Peran Public Relations dalam mempromosikan sebuah destinasi wisata merupakan salah satu cara mewujudkan hal tersebut.

Salah satu keunggulan utama yang dimiliki oleh Indonesia adalah keindahan alamnya. Salah satu yang menjadi lokasi destinasi wisata yang ditonjolkan oleh Indonesia adalah wisata pulau Lombok. Namun pada tanggal 5 Agustus 2018 terjadi bencana alam berupa gempa bumi, yang mengakibatkan terjadinya kerusakan alam yang ada di Lombok.

Beberapa saat setelah terjadinya peristiwa yang menimpa pulau Lombok, semua media baik nasional maupun internasional banyak yang menjadikannya headline berita pada media mereka. Lombok berusaha bangkit setelah terjadinya peristiwa tersebut dan kembali menata pariwisata. Pascagempa, beberapa tempat wisata sempat ditutup oleh pemerintah setempat dikarenakan kondisi pada saat itu belum stabil.

Adanya pemberitaan di media massa mengenai potensi wisata di kawasan Lombok dapat dijadikan modal dasar dalam mengembangkan kegiatan-kegiatan wisata yang berbasiskan keindahan alam, kekayaan kuliner, dan kearifan lokal. Pemberitaan mengenai potensi wisata di Lombok dapat mengubah konsep pariwisata sebagai pendorong utama bagi kemajuan ekonomi sosial di kawasan tersebut. Setelah terjadinya bencana gempa bumi pada Agustus 2018, Lombok kemballi melakukan revitalisasi dan perbaikan di berbagai bidang, salah satunya adalah infrastruktur. Selain itu, berbagai event dan atraksi kebudayaan yang merupakan bagian dari kegiatan promosi pariwisata yang dilakukan Dinas Kebudayaan dan Pariwisata Kota Lombok.

Tabel 1. Menonton berita tentang Lombok setiap hari

\begin{tabular}{lrc}
\hline & Jumah & $\%$ \\
\hline Setuju setuju & 34 & 51 \\
Sangat setuju & 6 & 39 \\
Sidak setuju & 23 & 35 \\
\hline
\end{tabular}

Penelitian melihat terpaan berita tentang Lombok Pasca Gempa sebagai sebuah upaya untuk memulihkan pariwisata. Tabel 1 menunjukan frekuensi calon wisatawan mendapatkan exposure berita Lombok setiap harinya. Hasil pada tabel tersebut menunjukkan bahwa calon wisatawan banyak yang menonton berita tentang Lombok setiap harinya. Setelah terjadinya gempa di Lombok, responden menonton/mendengar/melihat berita gempa tersebut setiap harinya. Media massa sebagai sarana integrasi dan interaksi memiliki kemampuan yang besar dalam menyebarkan pesanpesan dan informasi dalam komunikasi bencana. Semakin sering seseorang menonton/mendengar/ melihat sebuah berita, maka akan memberikan dampak terhadap perilaku penonton tersebut, baik pada peribahan perilaku kongnitif, afektif maupun behavioralnya.

Tabel 2. Menonton berita setidaknya 5-10 menit setiap hari

\begin{tabular}{lrr}
\hline & Jumah & $\%$ \\
\hline Setuju & 36 & 55 \\
Sanjatsetuju & 35 & 37 \\
Tidakssetuju & 25 & 3 \\
Sangattidaksetuju & 2 & \\
\hline
\end{tabular}

Tabel 2 menunjukan bahwa calon wisatawan menonton berita pasca gempa Lombok setidaknya 5-10 menit setiap harinya. Berita-berita yang disajikan di media televisi dikonsumsi oleh penonton selama 5-10 menit setiap harinya. Dengan sering dan lamanya seseorang terpapar oleh sebuah informasi, maka akan memberikan dampak terhadap perubahan perilaku penonton tersebut. Menonton televisi adalah suatu tindakan yang menarik yang tidak lepas dari dorongan dari masing-masing individu untuk menikmati apa yang ditayangkan oleh televisi, atau dengan kata lain tindakan menonton televisi adalah kesadaran 
seseorang terhadap sesuatu yang berhubungan dengan dorongan yang ada dalam diri individu sehingga seseorang memusatkan perhatiannya terhadap acara yang ditayangkan televisi dengan senang hati serta dengan perasaan puas sehingga pemirsa dapat menikmati apa yang ditayangkan oleh televisi tersebut. Sehingga dapat disimpulkan bahwa mononton merupakan aktivitas melihat sesuatu dengan tingkat perhatian tertentu.

Media massa selama ini memberikan pengaruh dalam memberitakan tentang isu-isu penting kepada khalayaknya (Choudhury yang dikutip Arianti, 2017:42). Dalam dunia pariwisata informasi yang disampaikan di media massa mempengaruhi konsumennya. Pada prinsipnya perilaku konsumen dipengaruhi afeksi dan kognisi konsumen terhadap informasi /stimulus yang diberikan oleh pemasar. Berita yang muncu di televisi secara tidak langsung dapat mempengaruhi pengetahuan dan tindakan seseorang dalam melakukan pilihan kunjungan destinasi pariwisata.

Penonton merupakan individu yang aktif dalam memilih atau menyeleksi berita. Teori Uses and effect menganggap bahwa khlayak memiliki kebebasan dalam memilih media yang akan mereka baca. Khalayak yang dianggap aktif, berarti khalayak dianggap sebagai bagian penting dari penggunaan media dan diasumsikan mempunyai tujan tertentu. Seseorang akan menggunakan media jika dirasa media tersebut dapat memenuhi kebutuhan informasinya. Berdasarkan penelitian yang dilakukan Arianti, Saleh dan Priatna (2015:49), lama waktu yang digunakan untuk membaca/menonton berita di media massa memiliki hubungan sangat nyata positif dengan frekuensi berita. Semakin lama khalayak membaca/menonton media massa sangat tergantung pada seberapa sering beritaberita tersebut dimuat di media massa. Sebagain besar calon wisatawan mengaku bahwa mereka menonton berita mengenai gempa Pulau Lombok 2018 dengan memperhatikan berita tersebut sampai akhir berita tersebut selesai.

Tabel 3. Menonton berita sampai selesai

\begin{tabular}{lrr}
\hline & Jumah & $\%$ \\
\hline Setuju & 38 & 57 \\
Sangatsetuju & 19 & 29 \\
Tidaksetuju & 19 & 3 \\
\hline
\end{tabular}

Sebagian besarcalon wisatawan mengakubahwa menonton berita pasca gempa Lombok dengan seksama dengan tidak mengganti channel stasiun televisi saat berita mengenai gempa Pulau Lombok 2018 sedang disiarkan. Hal ini menunjukkan bahwa responden memperhatikan setiap informasi yang disampaikan terkait peristiwa gempa di Lombok dan aktivitas pemulihan pasca gempa. Televisi adalah bagian yang menyatu dengan kehidupan sehari-hari dan menjadi sumber umum dari sosialisasi dan informasi bagi masyarakat.

Tabel 4 menyajikan informasi terkait responden yang memperhatikan isi berita terkait peristiwa gempa di Lombok yang disiarkan oleh televisi. Sebagian besar penonton memperhatikan isi berita yang ditayangkan di televisi tentang berita pasca terjadinya gempa di Lombok. Nilai berita menjadi salah satu unsur berita yang menjadi dominan dalam menentukan apakah berita tersebut akan dilihat, yang terbagi menjadi kepentingan, sifat dramatis, dan penekanan terhadap sesuatu selalu dapat menarik perhatian dan minat penonton.

Tabel 4. Memperhatikan isi berita

\begin{tabular}{lrr}
\hline & Jumah & $\%$ \\
\hline Setuju & 55 & 83 \\
Sangat setuju & 7 & 10 \\
Tidak setuuu & 3 & 5 \\
Sangat tidak setuju & 1 & 3 \\
\hline
\end{tabular}

Media audio visual merupakan salah satu jenis media komunikasi yang tampilannya selalu berkembang dan menarik bagi semua kalangan. Berbagai macam bentuk media dapat mempengaruhi cara berpikir dan gaya hidup seseorang. Bahkan seringkali tayangan-tayangan tersebut mengajarkan bagaimana cara untuk bertingkah laku dan menyikapi berbagai hal yang dapat saja terjadi dalam setiap sisi kehidupan masyarakat. Sebagian besar reponden memilih untuk memperhatikan berita mengenai gempa Pulau Lombok 2018 karena merasa bahwa berita tersebut menarik untuk diketahui dan mereka mengaku mengerti dengan jelas seluruh isi pesan yang disajikan pada berita tersebut.

Media dan komunikasi merupakan dua hal yang penting dalam hal menyebarkan dan menyalurkan informasi. Dalam kehidupan sebagian besar orang menghabiskan waktunya di depan TV, mendengarkan musik di mobil, membaca koran, majalah ataupun buku. Kondisi ini memberikan 
gambaran bahwa individu menghabiskan waktunya untuk 'mengkonsumsi' beragam bentuk media (Arianti, 2017:180).

Aspek media menjadi salah satu penyebabnya, yang sekaligus merubah pola kehidupan masyarakat. Nurudin 2017 (dalam Prasetya 2018) "Terpaan media massa yang demikian kuat itu telah memengaruhi sikap dan perilaku masyarakat. Bahkan, dalam keputusan sehari-hari masyarakat sering menjadikan informasi dari media massa sebagai referensi utama, tak terkecuali barangbarang yang dimilikinya".

Komunikasi selain bertujuan menginformasikan, juga dapat mempengaruhi perilaku penerima informasi. Teori Uses and Effect menyatakan bahwa kebutuhan hanya salah satu dari faktorfaktor yang menyebabkan terjadinya penggunaan media. Informasi yang disampaikan oleh media massa ataupun media online memberikan dampak terhadap perilaku masyarakat. Berita yang ditayangkan oleh televisi terkait kegiatan pasca gempa di Lombok memberikan dampak terhadap minat kunjungan wisatawan.

Tabel 5. Minat berkunjung ke Lombok

\begin{tabular}{ccc}
\hline & Jumah & $\%$ \\
\hline Setuju & 37 & 56 \\
Sangatsetuju & 9 & 14 \\
Tidaks setuju & 18 & 27 \\
Sangattidaksetuju & 2 & 3 \\
\hline
\end{tabular}

Dari Tabel 5 dapat dilihat bahwa sebagian besar calon wisatawan berminat untuk berkunjung ke Lombok pasca terjadinya gempa. Namun, terdapat sebagian kecil calon wisatawan dalam waktu dekat akan merencanakan berwisata ke Pulau Lombok pascagempa yang terjadi di Pulau Lombok pada tahun 2018. Calon wisatawan sebagian besar berpendapat tidak setuju dengan pernyataan akan berniat berkunjung ke Lombok karena promosi dan campaign mengenai destinasi wisata yang menarik di Pulau Lombok pasca gempa 2018. Berdasarkan hasil pengumpulan data disimpulkan bahwa calon wisatawan setuju bahwa mereka lebih aware terhadap pulau Lombok setelah menonton berita gempa Lombok.

Uji regresi digunakan untuk melihat seberapa besar variabel independent dapat menjelaskan variable dependentnya. Pada penelitian ini analisis yang digunakan adalah uji regresi linear sederhana dampak terpaan berita terhadap minat pariwisata pulau Lombok pasca gempa 2018.

Tabel 6. Model Summary

\begin{tabular}{|c|c|c|c|c|}
\hline Model & $\mathrm{R}$ & R Square & $\begin{array}{l}\text { Adjusted } \\
\text { Square }\end{array}$ & $\begin{array}{l}\text { RStd. Error o } \\
\text { Estimate }\end{array}$ \\
\hline 1 & $.298^{\mathrm{a}}$ & .089 & .075 & 4.75523 \\
\hline
\end{tabular}

Tabel 6 menjelaskan besarnya nilai korelasi atau hubungan (R) sebesar 0.298. Dari hasil tersebut diperoleh kesimpulan bahwa kontribusi pengaruh ( $\mathrm{R}$ square) sebesar 0.089, yang mengandung arti bahwa kontribusi pengaruh variabel bebas (terpaan berita) terhadap variabel terikat (minat pariwisata) adalah $8.9 \%$. Sedangkan sisanya, yaitu $91.1 \%$ dijelaskan oleh faktor lain. Hal ini menunjukkan bahwa, banyaknya media massa terutama televisi yang menyebarkan berita terkait bencana gempa bumi di Lombok, memiliki pengaruh yang rendah terhadap minat kunjungan wisatawan ke Lombok.

Peran media massa tidak hanya dilihat dari pengaruhnya terhadap psikologi dan pengetahuan, tetapi juga pada kemanfaatan yang dapat diambil oleh masyarakat untuk digunakan sebagai alat mengubah posisinya ketempat yang lebih baik. Televisi yang merupakan media massa yang memiliki kekuatan dalam mempengaruhi, persepsi, pandangan hingga perilaku audiens. Dasar dari teori ini yakni suatu kondisi dimana orang diterpa oleh isi media atau bagaimana isi media menerpa audiens. Hasil penelitian ini menunjukkan bahwa terdapat pengaruh signifikan positif exposure berita terhadap minat pariwisata ke Lombok pasca terjadinya gempa. Televisi yang merupakan media massa yang memiliki kekuatan dalam mempengaruhi, persepsi, pandangan hingga sikap audiens. Exposure berita memberikan kontribusi pengaruh sebesar $8.9 \%$ terhadap minat pariwisata.

Berkaitan dengan teori uses and effect, menjelaskan bahwa pilihan jenis dan isi media oleh khalayak akan memberikan pengaruh terhadap persepsi mereka, perbedaan ini pada akhirnya akan memberikan perbedaan terhadap perilaku khalayak tersebut. Minat wisatawan berkunjung ke pulau Lombok pasca gempa rendah, karena alasan tersendiri untuk mengunjungi pulau Lombok, dan promosi yang di lakukan pemerintah pasca gempa pulau Lombok. Terpaan berita yang memberikan kontribusi pengaruh adalah frekuensi dan 
durasi tayangan yang ditampilkan televisi pasca terjadinya gempak Lombok 2018. Media massa adalah institusi yang berperan sebagai agent of change, yaitu sebagai institusi pelopor perubahan. Media massa berperan sebagai institusi pencerahan masyarakat. Media massa menjadi media yang setiap saat medidikmasyarakat supaya cerdas, terbuka pikirannya dan siap menjadi masyarakat yang maju.

\section{SIMPULAN}

Berita yang ditampilan di media massa televisi memberikan dampak terhadap perilaku khalayaknya sesuai dengan teori uses and effect, dimana kebutuhan akan informasi akan mempengaruhi perilaku penerima informasi. Pasca terjadinya gempa di Lombok pada Agustus 2018, pemerintah daerah maupun pusat kembali melakukan penataan terhadap destinasi wisata di Lombok terutama untuk infrastruktur dan pemasaran pariwisatanya. Hasil penelitian ini menunjukkan bahwa terdapat pengaruh signifikan positif exposure berita terhadap minat pariwisata ke Lombok pasca terjadinya gempa. Televisi yang merupakan media massa yang memiliki kekuatan dalam mempengaruhi, persepsi, pandangan hingga sikap audiens. Exposure berita memberikan kontribusi pengaruh signifikan positif (sebesar $8.9 \%$ ) terhadap minat pariwisata. Oleh karena itu, Televisi dirasa memainkan peranan penting dalam penyebaran informasi dan memiliki kemampuan untuk mempengaruhi perilaku khalayak.

\section{DAFTAR PUSTAKA}

Arianti, Gusmia. 2017. Kepuasan Remaja Terhadap Penggunaan Media Sosial Instragram Dan Path. Jurnal WACANA. Vol. 16, No. 2 (2017). Page: 180-192

Arianti, Gusmia. Amiruddin Saleh dan Wahyu Budi Priatna. 2015. Persepsi Pembaca Tentang Berita Pembangunan di Surat Kabar Radar Bogor. Jurnal Komunikasi Pembangunan. Vol. 13. No. 1 (2015). Page: 42-53

Budianto, Heri, Prima Mulyasari, dan Nur Kholisoh. 2013. Marketing Communication Pariwisata Dan Korporasi Di Indonesia. Jakarta: Pusat Studi Komunikasi dan Bisnis Program Pasca Sarjana Universitas Mercu
Buana Jakarta.

Bungin, Burhan. 2015. Komunikasi Pariwisata (Tourism Communication) Pemasaran dan Brand Destinasi. Edisi Pertama. Jakarta: Prenadamedia Group

Febrina, Dian. 2018. Persepsi Wisatawan Mancanegara Terhadap Brand Pariwisata Wonderful Indonesia. Jurnal WACANA. Vol. 17, No. 1 (2018). Page: 72-81

Press Release. Humas Badan Meteorologi, Klimatologi, dan Geofisika (BMKG) RI. 2018. Gempa Lombok Berpotensi Tsunami, BMKG : Jauhi Bibir Pantai. https://www. bmkg.go.id/press-release/?p=gempalombok-berpotensi-tsunami-bmkg-jauhibibir-pantai\&tag $=$ press-release \&lang=ID

Kriantono, R. 2006. Riset Komunikasi. Jakarta: Kencana Prenada Media Group.

Kotler P dan Keller. 2007. Manajemen Pemasaran. Edisi 12. Jilid 1. Jakarta: PT. Indeks

Neuman, W. Lawrence. 2011. Social Research Methods: Qualitative and Quantitative Approaches. 7th Edition. Boston: Allyn\& Bacon.

Prasetya, Arif 2018. PengembanganKomunikasiPublik Dan PariwisataBerbasis Internet Pada Website Dinas Pariwisata Pemerintah Kota Malang. Jurnal WACANA. Vol. 17, No. 2 (2018). Page: $135-142$

Oktaria, Regina. 2018. Pengaruh Nation Branding "Pesona Indonesia" Terhadap Minat Berkunjung Wisatawan Nusantara (Survei Pada Pengikut Instagram @pesonaid travel). Universitas Multimedia Nusantara.

Rakhmat, J. 2011. Psikologi Komunikasi. Bandung: Remaja Rosdakarya.

Rejeki, Sri dan Gusmia Arianti. 2018. PR Now Praktik Public Relations di Era Disrupstif. Indonesia Public Relations Conference (IPRC).Yogyakarta. Page: 154-171

Sakti, Guntur. 2018. Siaran Pers : Lombok Terpilih sebagai Destinasi Wisata Halal Terbaik di Indonesia. http://www.kemenpar. go.id/post/siaran-pers-lombok-terpilihsebagai-destinasi-wisata-halal-terbaik-di- 
indonesia. diakses pada 20 Februari 2019.

Slamet. 2010. Belajar dengan Faktor-faktor yang Mempengaruhinya. Jakarta: Rineka Cipta.

Sumarwan. 2011. Perilaku Konsumen: Teori dan Penerapannya dalam Pemasaran. Bogor: Ghalia Indonesia.

Sumiyati dan Lilik Murdianto. 2018. Strategi Komunikasi Pemasaran Pariwisata Untuk Meningkatkan Kunjungan Wisatawan Di Pantai Suwuk Kabupaten Kebumen. Jurnal WACANA. Vol. 17, No. 2 (2018). Page: 171-180

Tim redaksi. 2018. MasterCard-Crescentrating Global Muslim Travel Index (GMTI) 2018. https://pressrelease.kontan.co.id/release/ mastercard-crescentrating-global-muslimtravel-index-gmti-2018 diakses pada 21 Desember 2018.
Tim redaksi. 2019. Pasca Gempa, Strategi Wisata Inilah yang Digenjot NTB. https://www. teras.id/life/pat-2/126226/pasca-gempastrategi-wisata-inilah-yang-digenjot-ntb diakses 20 Januari 2019

Woja, KM Ncuhi Soneo. 2018. Pariwisata Lombok Pasca Gempa. http://opiniartikel.kampungmedia.com/2018/11/09/pariwisatalombok-pasca-gempa-26960_diakses pada 20 Februari 2019.

Wahyuni, Nurseffi Dewi. 2014. 70\% Pulau di Indonesia Tak Berpenghuni. https://www. liputan6.com/bisnis/read/2108368/70pulau-di-indonesia-tak-berpenghuni diakses pada 20 Februari 2019.

Zalukhu, Sukawati \& Meyers, Koen. 2009. Panduan Dasar Pelaksanaan Ekowisata. Jakarta: Unesco Office. 